\title{
Household Energy Use and Travel: Opportunities for Behavioral Change
}

\author{
Sashank Musti \\ Graduate Student Researcher \\ The University of Texas at Austin \\ B.124 E. Cockrell Jr. Hall \\ Austin, TX 78712-1076 \\ sashankmnm@gmail.com \\ Katherine Kortum \\ Graduate Student Researcher The \\ University of Texas at Austin \\ B.124 E. Cockrell Jr. Hall \\ Austin, TX 78712-1076 \\ kkortum@gmail.com \\ Kara M. Kockelman \\ (Corresponding author) \\ Professor and William J. Murray Jr. Fellow \\ Department of Civil, Architectural and Environmental Engineering \\ The University of Texas at Austin \\ 6.9 E. Cockrell Jr. Hall \\ Austin, TX 78712-1076 \\ kkockelm@mail.utexas.edu \\ Phone: 512-471-0210 \& Fax: 512-475-8744
}

The following paper is a pre-print and the final publication can be found in Transportation Research Part D 16 (1):49-56, 2011.

\section{ABSTRACT}

Home and personal travel decisions have important consequences for greenhouse gas (GHG) emissions, yet there has been little data on and investigation into the connections between such decisions and decision makers' opinions on energy policy options. This study examines such data for the Austin metropolitan area and attempts to infer directions for fruitful energy policy.

Nearly all respondents recognized global warming as a problem (95\%), and most agreed that lifestyle changes are needed to combat climate change (85\%). Many also believe that climate change can be combated by application of stricter policies in the areas of vehicle technology (68\%), fuel economy (86\%), and building design (85\%). Results of the study illuminate the importance of home-zone attributes on vehicle ownership, vehicle miles, and emissions. Most (56\%) households agree that energy regulations should be pursued to curb global climate change, and most prefer caps on consumption over taxation. Data and empirical results suggest that substantial U.S. energy and greenhouse gas savings are likely to come from vehicle fuel-economy regulation, rebates on relatively fuel-efficient vehicle purchases, home heating and cooling practices, caps on maximum household energy use, and long-term behavioral shifts.

Key words: Household energy consumption, transport energy, climate change, greenhouse gas emissions 


\section{INTRODUCTION}

Rising energy prices, concerns about climate change, and national energy security are hot topics of debate, both globally and nationally. Reducing energy consumption directly addresses each of these issues. The US contains just $4 \%$ of the world's population but produces $25 \%$ of all greenhouse gas (GHG) emissions (BBC 2002). Transportation is responsible for 32\% of these emissions (EIA 2007), and residential energy demands another 21\% (EIA 2007). In the midst of such debate and details, information regarding households' current energy consumption via travel and home use will no doubt be helpful in crafting local, regional, and national policies to address climate change, energy security, and energy pricing issues. To this end, a detailed survey of energy use, practices, and opinions on energy and transportation policies was developed, and all completed responses are analyzed here.

Significant behavioral changes are often difficult to inspire and short-lived. Certain travel choices can be particularly resistant to change. While King et al. (2009, p. 34) found that "stated willingness to change behaviors is largely high", actual changes are more elusive; and "willingness to change transport behaviors is consistently lower than willingness to change non-transport (e.g., domestic) behaviors.” In addition, people would rather make changes in trip chaining, tire inflation, speeds, and even their destinations than mode choice (Bomberg and Kockelman, 2008; King et al., 2009).

Much of the choice behavior and attitudes toward transport, housing and associated energy demands cannot be explained by demographic factors (King et al., 2009). This study attempts to better understand these differences, specifically for the Austin, Texas population.

\section{DATA ACQUISITION}

\section{Questionnaire Design}

In fall 2008, graduate students at the University of Texas at Austin (UT) designed a 10-page selfcompletion questionnaire with five sections covering personal travel choices and opinions, vehicles owned, home design and energy use, opinions on energy policy, and basic demographics. They included ranking questions, multiple-choice questions, and stated and revealed preference questions.

The Transportation section focused on respondents' travel patterns - both short- and long-distance. It also asked questions to determine the stated response to both higher gas prices and lower transit fares. There were several questions on working from home and teleconferencing, asking if the respondent participated in either, and questions designed to better understand the reasons for such behaviors.

The Vehicles section asked for a listing of currently owned vehicles, annual vehicle-miles traveled (VMT) for each vehicle, and a ranking of key features in selecting a new vehicle. This section also asked a variety of questions to determine attitudes toward several different policies which encourage the purchase of energy-efficient vehicles.

In the Home Design and Energy Use section, questions emphasized household attributes, including monthly electric and natural gas consumption. The Energy Policy section described a variety of policy scenarios and asked whether the respondent would support or oppose each. For example, it asked about household energy use caps and increased energy costs, as well as the use of bio-fuels, nuclear power plants, and carbon capture and sequestration for reducing GHG emissions. Finally, in the Demographics section, the survey sought basic information such as age, household size, and income. 


\section{Survey Distribution}

A variety of techniques were used to distribute the survey to Austin-area residents. The most timeintensive technique consisted of canvassing homes across six strategically selected neighborhoods to distribute paper questionnaires, which was accomplished by three pairs of students over the course of two sequential weekends. Population data for all Austin neighborhoods was obtained from the Capital Area Metropolitan Planning Organization’s (CAMPO’s) 2005 estimates, and strategic sampling was used in order to ensure a variety of household demographics. The six neighborhoods (Westlake, Far West, Hyde Park, East Austin, Sunset Valley, and Manor) represent a valuable cross-section of the Austin region in terms of ethnicity, wealth, population density, and transit access. Cluster sampling of streets within each neighborhood was used, to moderate data acquisition time and costs. And managers of local apartment complexes were contacted ahead of time, in order to obtain permission to visit and distribute surveys.

The survey was also made available online (www.energysurvey.co.nr) in order to reach a wider audience. In addition to canvassing neighborhoods, the team created flyers with tear-off tabs containing the survey's URL. These flyers were posted in apartment laundry rooms, on community bulletin boards, and on UT Austin information poles. The team also handed out surveys in front of the Central Market grocery store's North Lamar location in an attempt to reach people outside of the University realm and outside the sampled neighborhoods. And the team created small cards with a short description of the survey and its URL and left these in public places, as well as with those who were too busy to complete the paper survey on site.

Students with ties to the Austin community handed out surveys to friends and family. Finally, the team enlisted the help of 160 community organizations, from the regional transit agency and the University of Texas to the lesser-known Austin Pug Club and Heart of Texas Orchid Society, to distribute the survey's URL through their networks.

\section{DATA DESCRIPTION}

Table 1 provides summary statistics for demographic attributes in the data set, along with values from the Census 2000 for Austin individuals. While sample gender, age, household size, and worker-count values are in line with Census values, there are certainly more students in the sample than in the overall population which is not unexpected, since the internet sample was somewhat more heavily targeted towards UT student groups. The sample is also biased towards more educated persons, with $73 \%$ of respondents holding a bachelor's degree or higher. This is also reflected in the sample's very high average income, as compared to the Census 2000 value (which was acquired 8 years earlier in time, so inflation might account for a 25-percent difference). The average number of vehicles per household in the sample is 1.46, which is quite a bit lower than the 2.34 mean in Austin's recent travel survey.

Table 1: Summary of Unweighted Respondent Attributes $(\mathbf{n}=\mathbf{8 5 6})$

\begin{tabular}{|l|c|c|c|c|c|}
\hline Variable & Minimum & Maximum & Average & $\begin{array}{c}\text { Standard } \\
\text { Deviation }\end{array}$ & $\begin{array}{c}\text { Census 2000 } \\
\text { Average }\end{array}$ \\
\hline Number of vehicles & 0 & 5 & 1.461 & 0.820 & $2.34^{*}$ \\
\hline “Own home” indicator & 0 & 1 & 0.652 & 0.477 & 0.448 \\
\hline Number of household members & 1 & 26 & 2.538 & 2.018 & 2.40 \\
\hline Number of household workers & 0 & 20 & 1.577 & 1.450 & 1.33 \\
\hline Student status indicator & 0 & 1 & 0.814 & 0.389 & 0.123 \\
\hline Age (years) & 20 & 70 & 38.83 & 14.80 & 32.34 \\
\hline
\end{tabular}




\begin{tabular}{|l|c|c|c|c|c|}
\hline Female indicator & 0 & 1 & 0.497 & 0.500 & 0.510 \\
\hline Household income (\$/year) & 5,000 & 200,000 & 82,056 & 53,900 & 47,212 \\
\hline $\begin{array}{l}\text { College-educated (has attained } \\
\text { Bachelor’s degree or higher) }\end{array}$ & 0 & 1 & 0.734 & 0.442 & 0.404 \\
\hline
\end{tabular}

* Vehicle ownership statistics come from the 2006/2007 Austin Travel Survey.

In order to address various demographic biases, sampling weights were assigned to each respondent and his/her associated household according to their demographic representation in the data set, relative to the region's 3-county population. All records were weighted, though some records did not have all desired demographic information to weight properly. The initial sample size was 1,200 respondents, but only 856 could be assigned weights. In other words, 344 records were lacking some of the demographic information used to compute the weights (due to item non-response), so these were removed from subsequent analyses.

The sample set was divided into 720 categories (in a multi-dimensional space) based on gender (male, female), age (six categories), worker status (worker, non-worker), student status (student, non-student), household size $(1,2,3,4,5+)$ and household income categories (low $[<\$ 30,000$ per year], medium [\$30,000 to \$75,000] and high [>\$75,000]) using the Census 2000’s 5\% Public Use Microdata Sample (PUMS). Cells housing zero counts (in either the sample or PUMS data sets) were merged with adjacent cells. Ratios of census-to-sample counts were then normalized, resulting in 856 usable records for data analysis.

\section{Geo-coding}

Respondents' home addresses were geo-coded using TransCAD ® software and matched to Austin's database of traffic analysis zones (TAZs). The questionnaire requested home addresses, but not all respondents provided usable location information. Presumably to preserve privacy, some respondents provided only zip codes, which could not be linked to a particular TAZ. Others left the question entirely blank. In addition, addresses along relatively new streets could not be found using TransCAD, so manual geocoding was performed on those records (using various maps). Due to non-response, response error, and other matching issues, only 717 (84\% of the 856 weighted records) were geo-coded to a TAZ.

Supplementary datasets were prepared for the three-county Austin region using CAMPO land use data for the year 2000 and CAMPO's 1997 road network. These datasets provide variables like household and population counts; household, population, and neighborhood densities; employment counts (by industry sector); property values; and network distances to the region's central business district (CBD), the UT campus, and Austin's international airport at the spatial scale of TAZs. Thanks to this process, each geo-coded survey record could be assigned a variety of home-based locational attributes. Summary statistics on these are presented later in the paper.

\section{RESULTS}

Using these 717 respondent records, a variety of descriptive statistics characterizing (populationweighted) responses to various important questions emerge. For example, respondents were asked what actions they thought the government and public should take to control greenhouse gas emissions. Most (84\%) agree that lifestyle changes are necessary to combat the problems of global warming and climate change. And 69\% believe that research and development of new technologies will provide solutions to such problems. Far fewer people (16\%) were willing to live with restrictions on their own greenhouse gas emissions, underscoring the inertia present in individuals when changes in personal behavior are 
involved (e.g., Gärling and Axhausen, 2003; Kitamura and van der Hoon, 1987). Nevertheless, very few believe that global warming is not a problem (5\%) or that nothing should be done (3\%).

Figure 1 illustrates responses to questions regarding perceptions about climate change, willingness to accept personal responsibility for this change, and opinions on regulating options. These results are generally consistent with Curry et al.'s (2007) findings, which showed a rise in American's awareness of the global warming problem over time, as $49 \%$ of respondents considered it to be one of the top two most important problems in 2006, as compared to only $21 \%$ in 2003 . These results are also very consistent with Smith et al.'s (2009) recent findings that $46 \%$ of the sampled Americans believe “carbon emissions from my vehicle contribute to climate change”. In this survey, nearly all respondents (95\%, population-corrected) agree with the statement that it is everyone's duty to reduce energy use and protect the environment. Also, many individuals seem to believe that current levels of energy use are changing the climate rapidly.

Two possible for combating climate change (direct taxation of energy use and a cap on energy use) were introduced in this survey. As Figure 1 suggests, 48\% of respondents agreed at some level with taxing energy use, while only $41 \%$ agreed with capping household energy use.

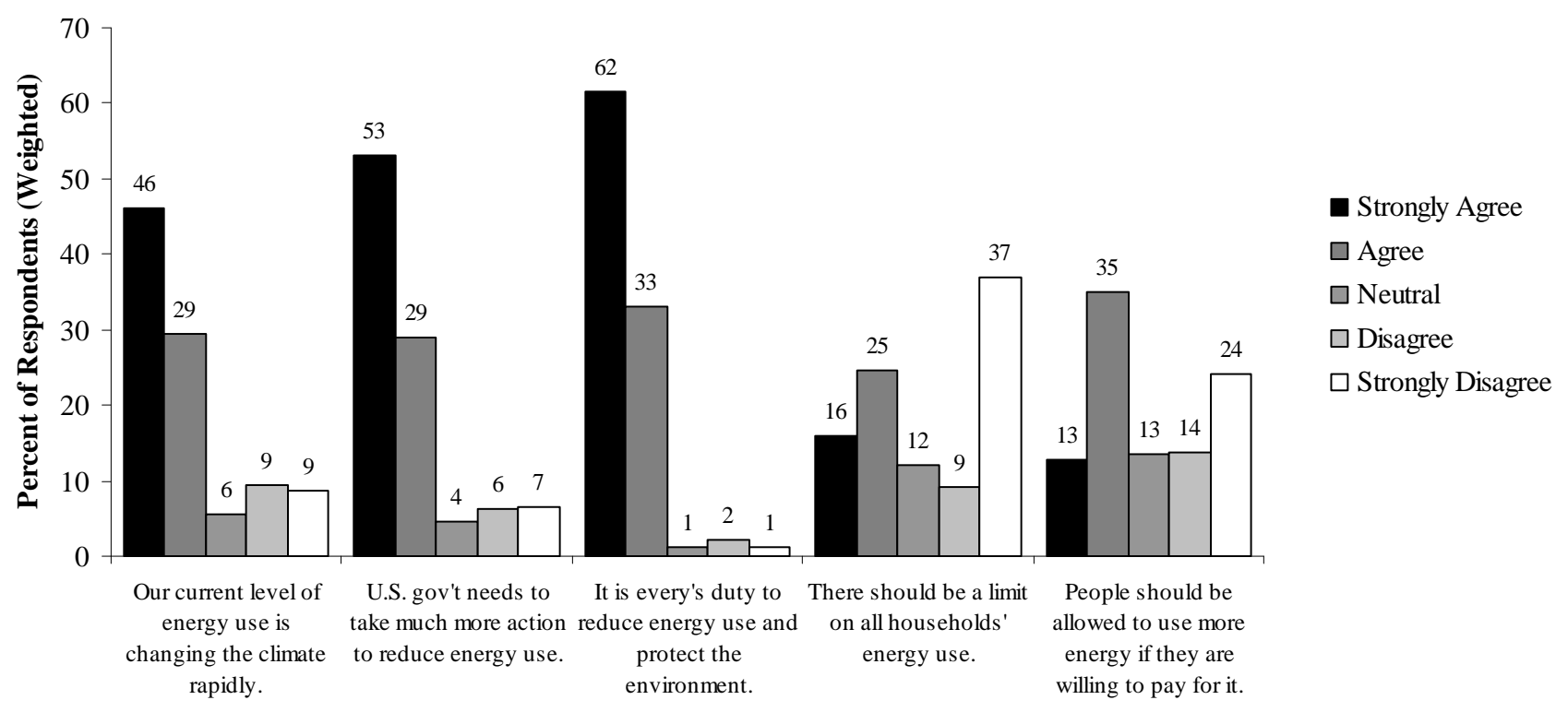

Figure 1: Opinions on Climate Change Responsibility and Regulation

Table 2 shows levels of support stated for different policies to combat climate change. The most strongly supported policy measure (the measure with the lowest average score) is an increase in vehicle fuel economy standards. Stricter appliance and building efficiency standards are also relatively favored. These may be popular because they do not involve any direct impact on individual lifestyles.

Table 2: Statistics on Support for Policies to Combat Climate Change (Weighted)

\begin{tabular}{|l|c|c|}
\hline & $\begin{array}{c}\text { Average } \\
\text { Response } \\
\text { (1=Strongly } \\
\text { Support) }\end{array}$ & $\begin{array}{c}\text { Standard } \\
\text { Deviation of } \\
\text { Response } \\
\text { Values }\end{array}$ \\
\hline Stricter vehicle fuel economy standards (example: 40 mpg fleet average) & 1.60 & 1.03 \\
\hline Require strict energy efficiency standards on virtually all new buildings & 1.66 & 0.98 \\
\hline $\begin{array}{l}\text { Offer rebates to consumers for purchasing very fuel efficient vehicles (like hybrid \& plug-in } \\
\text { hybrid vehicles) }\end{array}$ & 1.73 & 1.05 \\
\hline
\end{tabular}




\begin{tabular}{|l|c|c|}
\hline Require Energy Star ${ }^{\mathrm{TM}}$ standards on all household appliances & 1.74 & 1.02 \\
\hline $\begin{array}{l}\text { Carbon capture \& sequestration (where GHG emissions are stored, rather than allowed to enter the } \\
\text { atmosphere) }\end{array}$ & 2.32 & 1.04 \\
\hline Impose a limit on GHG emissions and allow trading of purchased emission credits & 2.34 & 1.17 \\
\hline $\begin{array}{l}\text { Energy taxes (example: \$50 per ton of GHG produced by electricity generation and motor fuel } \\
\text { use) }\end{array}$ & 2.40 & 1.21 \\
\hline Triple nation's production of biofuels & 2.73 & 1.24 \\
\hline Build 5+ nuclear power plants & 2.74 & 1.37 \\
\hline Increase motor fuel taxes by \$1 per gallon & 2.94 & 1.49 \\
\hline
\end{tabular}

Note: 1 indicates “strongly support,” 2 indicates “somewhat support,” 3 indicates “neutral,” 4 indicates "somewhat oppose,” and 5 indicates "strongly oppose.

Interestingly, the least popular policy option is a motor fuel tax increase. The lack of increase in this tax recently pushed the Highway Trust Fund to a zero balance, for the first time in history, and twice in the past two years. Many have found that gas prices have relatively little impact on behavior (e.g., Small and van Dender, 2007; Puller and Greening, 1999), so such taxes would have to be quite steep to engender much change (well over \$1 per gallon [as discussed in Kockelman et al. 2009]). Car buyers tend to heavily discount future fuel savings and/or largely ignore a vehicle's fuel economy benefits, so many experts argue for increased fuel efficiency standards (e.g., Greene et al., 1999; Goldberg 1998; Thorpe 1997). While the Obama Administration recently increased light-duty-vehicle standards to 35 mpg by 2016, the U.S. sales fleet presently averages 25 mpg, while the European Union averages 42 mpg and Japan averages $47 \mathrm{mpg}$ (An and Sauer 2004). This was the second most popular option, as shown in Table 2.

Other relatively unpopular survey options are nuclear power plants and biofuels. While much potential savings has been associated with these two options, the true long-term, life-cycle carbon implications of these energy sources have recently been questioned, in both technical and non-technical literature (Searchinger et al., 2008, Clayton, 2007). Thus, it is not clear whether the nation should or even can pursue these two options to any significant degree.

Stricter stricter energy efficiency standards on new buildings appears to be the least controversial policy option given in the survey, with a response standard deviation of just 0.98. Requiring Energy Star standards on all household appliances was very close behind, at 1.02. Both of these options probably are perceived as requiring relatively little effort or cost (on the part of respondents), thus resulting in their relative popularity. In contrast, increasing motor fuel taxes by $\$ 1 /$ gallon was the most controversial option, with a standard deviation of 1.49. The obvious cost implications and potentially significant impact this option may have on individuals and families creates division in opinions.

Figure 2's pie charts show the distribution of responses to the energy cap and tax policy questions. In general, respondents tend to favor caps over taxes. This may be because Austinites' with moderate to high incomes expect that they can afford such expenditures and are not in favor of making lifestyle changes under a capping policy. A correlation of just 0.17 exists between the two ordered responses, highlighting the diversity of opinion across these two options in tandem. In other words, a fair share of respondents support the capping option but not taxation (22.0\%), while similar shares agree with both (21.4\%) and disagree with both (17.3\%). 


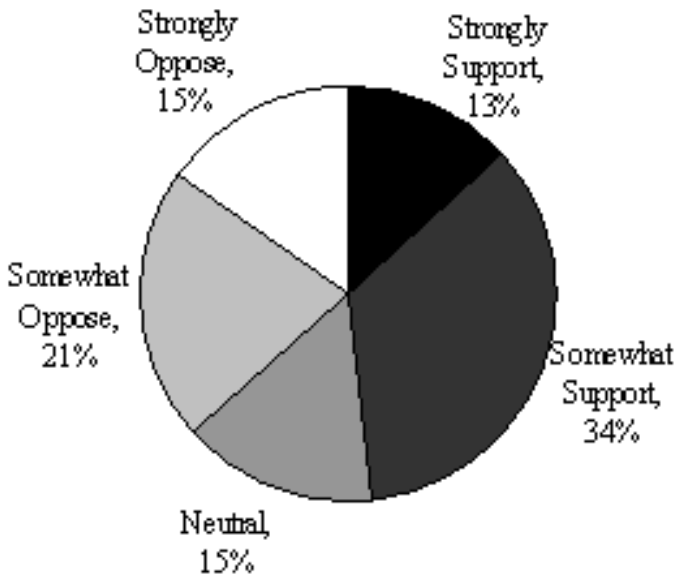

3(a)

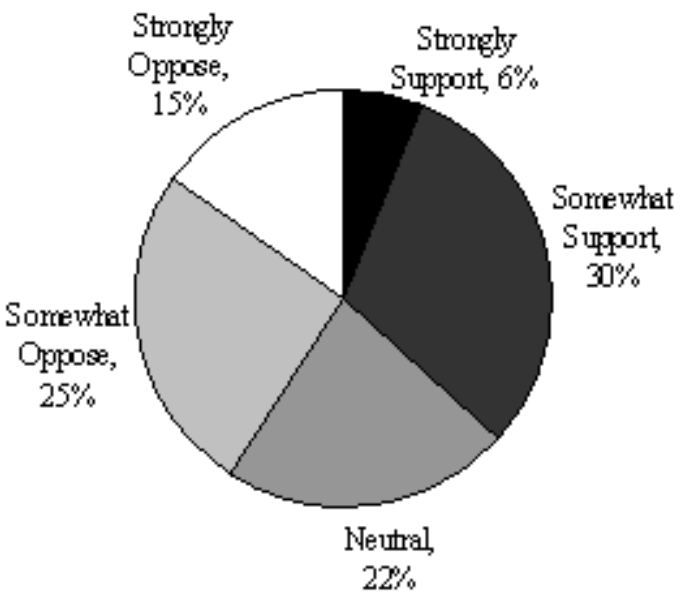

3(b)

Figure 2 (a) Response for Capping Household Energy Consumed \& (b) Response for Taxing all Energy Use

\section{REGRESSION MODEL RESULTS}

Several behavioral and stated choice models were run using the sample data. Table 3 provides summary statistics of all response variables and associated covariates. The regression models include weighted least squares analyses of vehicle fuel economy and annual VMT per household member, home size, and average monthly power use. Count models were used to estimate vehicle ownership levels, a binary probit was used to evaluate opinions regarding climate change actions, and a bivariate ordered probit model was used to analyze opinions on paired regulatory options.

Table 3: Summary Statistics of Sample Responses (Unweighted)

\begin{tabular}{|c|c|c|c|c|}
\hline Variables & $\begin{array}{l}\text { Minimum } \\
\text { Value }\end{array}$ & $\begin{array}{l}\text { Maximum } \\
\text { Value }\end{array}$ & $\begin{array}{l}\text { Average } \\
\text { Value }\end{array}$ & $\begin{array}{l}\text { Standard } \\
\text { Deviation }\end{array}$ \\
\hline \multicolumn{5}{|l|}{ Dependent Variables } \\
\hline Weighted average fuel economy & 14.67 & 26.60 & 18.70 & 2.87 \\
\hline Annual VMT per person (miles) & 0 & 62,500 & 7,662 & 6,801 \\
\hline Home size (square feet) & 500 & 5,000 & 1,686 & 855.9 \\
\hline Monthly electricity consumption $(\mathrm{kWh})$ & 200 & 8,793 & 1,771 & 1,487 \\
\hline Vehicles per household & 0 & 5 & 1.461 & 0.820 \\
\hline Adapt to a warmer climate & 0 & 1 & 0.2745 & 0.4465 \\
\hline Regulations should be imposed & 0 & 1 & 0.5981 & 0.4906 \\
\hline Cap on maximum energy use & 1 & 5 & 2.798 & 1.304 \\
\hline Tax on all energy use & 1 & 5 & 3.163 & 1.232 \\
\hline \multicolumn{5}{|l|}{ Independent Variables } \\
\hline \multicolumn{5}{|l|}{ Location Variables } \\
\hline $\begin{array}{l}\text { Distance to CBD (from centroid of home TAZ to Austin's } \\
\text { CBD, in network miles) }\end{array}$ & 0 & 33.3 & 5.731 & 5.271 \\
\hline Population density (persons per acre in home TAZ) & 0 & 29.67 & 4.295 & 3.68 \\
\hline Population density of zone if more than 6 miles from CBD) & 0 & 14.46 & 0.9074 & 2.011 \\
\hline Job density (jobs per acre in household's TAZ) & $1.821 \mathrm{E}-03$ & 152.1 & 7.582 & 20.77 \\
\hline Household density (households per acre in TAZ) & 0 & 78.95 & 1.170 & 2.955 \\
\hline Median household income of TAZ & 0 & 169,634 & 41,347 & 26,347 \\
\hline Number of transit stops in home TAZ & 0 & 254 & 24.84 & 40.91 \\
\hline Rural Indicator** & 0 & 1 & 0.4711 & 0.4994 \\
\hline \multicolumn{5}{|l|}{ Individual Variables } \\
\hline Age of respondent (years) & 20 & 70 & 38.83 & 14.80 \\
\hline
\end{tabular}




\begin{tabular}{|c|c|c|c|c|}
\hline College-educated (has attained Bachelor's degree or higher) & 0 & 1 & 0.734 & 0.442 \\
\hline $\begin{array}{l}\text { Worker status (indicator variable for whether or not the } \\
\text { respondent is employed) }\end{array}$ & 0 & 1 & 0.37 & 0.49 \\
\hline Presence of children in a household * Urban indicator & 0 & 1 & 0.0545 & 0.2271 \\
\hline \multicolumn{5}{|l|}{ Household Variables } \\
\hline Household size & 1 & 26 & 2.538 & 2.018 \\
\hline Number of children & 0 & 4 & 0.4 & 0.821 \\
\hline Number of adults & 1 & 26 & 2.178 & 1.997 \\
\hline Number of workers & 0 & 20 & 1.577 & 1.450 \\
\hline Income of household $(\$ 1,000)$ & 5 & 200 & 82.06 & 53.95 \\
\hline $\begin{array}{l}\text { Income per person (household income / household size, } \\
\$ 1,000)\end{array}$ & 1.25 & 175 & 37.58 & 25.94 \\
\hline Number of vehicles & 0 & 5 & 1.461 & 0.820 \\
\hline Annual VMT per household member & 0 & 62,500 & 7,662 & 6,801 \\
\hline $\begin{array}{l}\text { Own home (household owns home or is paying off mortgage, } \\
\text { rather than renting) }\end{array}$ & 0 & 1 & 0.652 & 0.477 \\
\hline \multicolumn{5}{|l|}{ Dwelling Unit Variables } \\
\hline Home size (square feet) & 500 & 5,000 & 1,686 & 855.9 \\
\hline Age of home (years) & 0 & 59 & 32.25 & 17.90 \\
\hline Two- \& three-story detached home indicator & 0 & 1 & 0.249 & 0.433 \\
\hline Rooms in home & 1 & 14 & 5.013 & 2.314 \\
\hline
\end{tabular}

** Zones were coded by CAMPO based on a TxDOT formula using combination of employment and household density values- with thresholds of 8,3 and 1 person-equivalents per acre for urban, suburban and rural area respectively. Equivalent population is simply zone population plus zone employment times the regional persons-per-job ratio.

\section{Vehicle Fuel Economy}

Weighted least squares regression was used to estimate the (average) fuel economy of each household's vehicle holdings. To do this, within each household's vehicle fleet a weighted harmonic averaging process was used, to get at effective miles per gallon (with weights of annual VMT per vehicle). Data on 2007 model year purchase price, engine size (in liters), and fuel economy were obtained for each make and model from Ward's Automotive Yearbook (2007). Average values of fuel economy for each vehicle class (i.e., mid-size, compact, subcompact, etc.) were used, depending on the vehicle types owned by the household. Model results are shown in Table 4. Several different variable specifications (including direct variable effects and interaction effects) were explored. The final specification was obtained based on a systematic process of eliminating variables that did not show practical significance or statistical significance at the 95\% confidence level. Variables with practical significance were kept in the model specification even if they had a much lower t-stat value.

Table 4: WLS Regression Results for Household Average Fuel Economy

\begin{tabular}{|l|c|c|c|}
\hline Variable & Coefficient & T-Statistic & $\begin{array}{c}\text { Mean } \\
\text { Elasticity }\end{array}$ \\
\hline Constant & 17.907 & 44.92 & - \\
\hline Age of respondent & -0.0069 & -1.15 & -0.0203 \\
\hline Female indicator & 1.135 & 5.97 & 0.0382 \\
\hline $\begin{array}{l}\text { College educated (has attained Bachelor's } \\
\text { degree or higher) }\end{array}$ & 0.7312 & 3.50 & 0.0055 \\
\hline Income of household & $-3.70 \mathrm{E}-06$ & -1.96 & -0.0159 \\
\hline Number of adults & 0.1219 & 2.21 & 0.0182 \\
\hline Presence of children x Urban indicator & -1.277 & -4.04 & -0.0050 \\
\hline Rural indicator & -0.6004 & -1.69 & -0.0064 \\
\hline Distance to CBD & -0.7558 & -2.53 & -0.3060 \\
\hline $\mathrm{R}^{2}$ & & 0.1272 & \\
\hline
\end{tabular}


Adjusted $\mathrm{R}^{2}$

0.1165

Notes: Weighted least squares (WLS) regression was used; $\mathrm{y}$ = VMT-weighted harmonic average of household's vehicles' fuel economies; $n=661$ (zero-vehicle households were not included). Elasticities were evaluated at each record's attributes and then averaged, to provide a mean elasticity across households/respondents.

Interestingly, women and those with Bachelor's degrees report having the most fuel efficient fleets (per mile actually traveled each year in the vehicles owned by such households). These two attributes are the most practically significant, as evidenced by their elasticity values (shown in Table 3's final column). As expected, higher incomes are associated with less efficient fleets (and, no doubt, heavier, larger vehicles, including full-size SUVs, for example) Older persons and those living in rural areas tend to rely on less efficient vehicles, which is consistent with findings by others (e.g., Fang, 2008 and Zhao and Kockelman, 2001). Finally, a household's effective fuel economy tends to fall with longer annual driving distances, which may be due to more remote home locations or the need for more flexible vehicles when taking long trips which can also be observed through the large elasticity value. In general, elasticities are small, though the model's fit is reasonable.

\section{Annual VMT per Person}

A weighted least squares regression was also used to predict annual VMT per household member. The results of this model are shown in Table 5.

Table 5: WLS Regression Results for Annual VMT per Person

\begin{tabular}{|l|c|c|c|}
\hline Variable & Coefficient & T-statistic & Mean Elasticity \\
\hline Constant & 5903 & 5.30 & - \\
\hline Population density of zone if more than 6 miles from CBD & -209.49 & -1.68 & -0.023 \\
\hline Population density & 124.6 & 1.71 & 0.069 \\
\hline Distance to CBD & 314.4 & 5.42 & 0.231 \\
\hline Number of transit stops in a TAZ ${ }^{1}$ & -16.34 & -2.18 & -0.054 \\
\hline College-educated & -1437 & -2.67 & -0.135 \\
\hline Income per person & 0.0203 & 1.77 & 0.099 \\
\hline Number of children & -1385 & -5.48 & -0.071 \\
\hline Age of respondent & 25.46 & 1.46 & 0.127 \\
\hline $\mathrm{R}^{2}$ & & 0.1289 & \\
\hline Adjusted $\mathrm{R}^{2}$ & & 0.1191 \\
\hline
\end{tabular}

Notes: Weighted least squares (WLS) regression was used, $\mathrm{y}=$ annual VMT per person in a household, and $\mathrm{n}=601$. Elasticities were evaluated at each record's attributes and then averaged, to provide a mean elasticity across households/respondents.

As expected, household distance to the region's CBD, income per household member, and respondent age are associated with higher VMT per person, thanks to longer trip distances and/or greater tripmaking engagements. Such VMT is predicted to fall with the presence of added children, respondent education and transit access. The density and distance-to-CBD variables are positively correlated $(\rho=$ 0.24), thus resulting in an unexpected sign on density. But the expected negative sign emerges for those zones over six miles from the region's center. In general, results are as expected, with the distance-toCBD variable offering the greatest practical significance, following by respondent age and income. Finally, results show that longer annual driving distances contribute to more fuel consumption and hence

\footnotetext{
${ }^{1}$ Due to statistical insignificance of transit stop density (of a home TAZ) in the model specification, number of transit stops was used and a t-stat of -2.18 was observed.
} 
more emissions (negative coefficients for the vehicle fuel economy and annual VMT per person model). Household vehicle fleet changes need to be made in order to tackle pollution and emissions.

\section{Home Size and Monthly Electricity Consumption}

A weighted least squares regression also was used to predict the size and monthly electricity demands of a home. Table 6's dependent variables include the total square footage of dwelling units and the monthly kWh (average of summer and winter months) consumed by respondent households.

Table 6: WLS Regression Results for Home Size and Monthly Electricity Consumption

\begin{tabular}{|l|c|c|c|c|c|c|}
\hline & \multicolumn{2}{|c|}{ Square Footage of Home (SF) } & \multicolumn{2}{c|}{ Monthly Electricity (kWh) } \\
\hline Independent Variables & Coefficient & $\begin{array}{c}\text { T- } \\
\text { statistic }\end{array}$ & $\begin{array}{c}\text { Mean } \\
\text { Elasticity }\end{array}$ & Coefficient & T-statistic & $\begin{array}{c}\text { Mean } \\
\text { Elasticity }\end{array}$ \\
\hline Constant & 1006 & 8.28 & - & 701.9 & 4.15 & - \\
\hline Household size & 44.16 & 1.55 & 0.0669 & 77.30 & 2.95 & 0.1109 \\
\hline Worker status & 143.1 & 1.80 & 0.0316 & - & - & - \\
\hline Income of household (\$1,000) & $3.9 \mathrm{E}-03$ & 6.39 & 0.1897 & $1.164 \mathrm{E}-03$ & 1.13 & 0.0540 \\
\hline College-educated & -221.8 & -3.72 & -0.097 & - & - & - \\
\hline Age of home & -9.09 & -5.77 & -0.1754 & 2.70 & 1.05 & 0.0491 \\
\hline Own home & 424.5 & 5.41 & 0.1654 & -186.7 & -1.42 & -0.0688 \\
\hline Number of vehicles & 222.7 & 5.28 & 0.1946 & - & - & - \\
\hline Number of adults & 65.15 & 1.98 & 0.0849 & - & - & - \\
\hline Job density & -1.718 & -1.83 & -0.0077 & - & - & - \\
\hline Population density & -21.19 & -2.94 & -0.0544 & -25.05 & -0.98 & -0.0608 \\
\hline Two- \& three-story detached home indicator ${ }^{2}$ & - & - & - & 355.2 & 3.26 & 0.05 \\
\hline Home size & - & - & - & 0.4918 & 6.46 & 0.4687 \\
\hline $\mathrm{R}^{2}$ & \multicolumn{7}{|l|}{0.3646} & & & 0.1958 & \\
\hline Adjusted R & & 0.3542 & & & 0.1844 & \\
\hline
\end{tabular}

Notes: Weighted least squares (WLS) regression was used, $\mathrm{y}=$ Square footage of home and kWh consumed per month, and $\mathrm{n}=510$. Elasticities were evaluated at each record's attributes and then averaged, to provide a mean elasticity across households/respondents.

Home size is obviously more stable over time for most households, and here more readily predicted than power consumption, thanks to an adjusted $\mathrm{R}^{2}$ of 0.354 (as compared to 0.184 ). The estimated effects of Table 6's explanatory variables on home size and electricity consumption follow expected trends.

Average single-family home size has increased about 1\% per year, on average, since 1978, from 1,750 to 2,500 square feet (NAHB, 2008). The trend shown in this model reflects this historical relationship because, as a home ages by one year, its size is predicted to decrease by approximately 7 square feet. Lack of home ownership is a strong indicator for multi-family units, with owned homes averaging 283 square feet larger here, ceteris paribus. Square footage also rises with household size, vehicle ownership, and income, as expected. Interestingly, vehicle ownership, income, and home age are the strongest predictors of home size, in terms of their practical significance (as indicated by elasticity values).

Respondent-given values of monthly kWh were not deemed reliable in many cases, and about 34\% of the survey's item non-response was found on the energy consumption questions. (Respondents were

\footnotetext{
${ }^{2}$ Indicator variables for type of household unit such as multifamily units, apartments and condominiums were found to be statistically insignificant.
} 
asked to provide information on energy consumed during summer and winter months. Some values had to be modified because some respondents reported their complete summer electricity usage (June through August) or winter electricity usage (December through February). And outliers were removed from analysis.) Nevertheless, these estimates are in line with the nation's 2001 Residential Energy Consumption Survey (RECS), which includes data for 4,822 U.S. households. Regression models using the RECS data suggest that the addition of one household member or 100 square feet of space will increase average monthly household energy consumption by $104 \mathrm{kWh}$ and $22 \mathrm{kWh}$, respectively. Results from this Austin sample suggest something similar, on the order of $90 \mathrm{kWh}$ and $60 \mathrm{kWh}$, respectively. The mean U.S. values for kWh consumed per month and home size in the RECS data are $900 \mathrm{kWh}$ and 2,100 square feet, respectively. Comparatively, these Austin data average 1,200 kWh and 1,645 square feet. Though Austin home sizes may be smaller, the hot summers result in higher-thanU.S.-average electricity demand.

\section{Number of Vehicles Owned by a Household}

To estimate vehicle ownership levels, negative binomial and Poisson count model specifications were used, with the data suggesting the simpler, nested Poisson specification. Table 7 gives these results.

Table 7: Model Results for Number of Vehicles Owned by a Household

\begin{tabular}{|l|c|c|c|}
\hline Independent Variables & Coefficient & T-statistic & $\begin{array}{c}\text { Mean } \\
\text { Elasticity }\end{array}$ \\
\hline Constant & -0.1572 & -1.29 & - \\
\hline Household Size & 0.03949 & 2.75 & 0.1002 \\
\hline Income per person (total income/household size) & $1.82 \mathrm{E}-06$ & 1.30 & 0.0684 \\
\hline Age of respondent & $2.50 \mathrm{E}-03$ & 1.17 & 0.0970 \\
\hline Own home & 0.3619 & 4.45 & 0.2360 \\
\hline Region-Specific Variables & & \\
\hline Distance to CBD & $9.50 \mathrm{E}-03$ & 1.68 & 0.0544 \\
\hline Job density (jobs per acre in TAZ) & $-4.00 \mathrm{E}-03$ & -1.54 & -0.303 \\
\hline Log Likelihood at Convergence & \multicolumn{3}{|l}{-946.9} \\
\hline Pseudo R ${ }^{2}$ & & 0.0300 & \\
\hline
\end{tabular}

Notes: Weighted least squares (WLS) regression was used, $\mathrm{y}=$ Number of vehicles in a household, and $\mathrm{n}=716$. Elasticities were evaluated at each record's attributes and then averaged, to provide a mean elasticity across households/respondents.

As income per person rises, ownership levels also rise - an intuitive result thanks to higher disposable income. Home owners also tend to own more vehicles than renters, everything else constant, and this indicator variable registers as the second most practically significant of all covariates. The most practically significant is job density, with a striking elasticity value of -0.303: as jobs density doubles, vehicle ownership levels may fall by 30 percent, suggesting that density (or the attributes for which it proxies, such as regional access, central location, and land use balance) could have significant benefits for reduced vehicle and energy use in this country. Additionally, as distance to the CBD falls, the number of vehicles falls, providing a type of "double dividend”, since a high share of jobs are centrally located (53\% jobs centrally located). These results complement Fang's (2008) recent findings and those of Zhao and Kockelman (2001), which suggest that population density (at the home zone) is practically (and statistically) significant in vehicle ownership decisions. Prillwitz et al. (2008) describe the impact of change in demographic attributes such as birth of a first child and increase in household income associated with increase in car ownership using the German panel data. The authors also suggest that the relocation of households from a central area to another central area cause a decrease in car ownership 


\section{Opinions on Tackling Climate Change ${ }^{3}$}

As shown in Table 3, significant shares of respondents agree that the U.S. should regulate all kinds of energy use and that Americans should not simply adapt to a warmer climate (56.1\%). Nevertheless, there is a fair bit of disagreement, and correlation between the two responses is just +0.08 . No significant correlation in latent error terms was found when applying a bivarate probit model (after controlling for various explanatory information), so independent binary probit models were used to illuminate respondents' opinions on these two questions.

As Table 8 results suggest, people who own more vehicles, workers, and males are all less likely to favor regulations being imposed on energy use and more likely to feel that we need to adapt to a warmer climate. Those who own more vehicles, of course, may be less willing to modify their more vehicleinvested behaviors. It is not clear why workers and males would be more likely to not support regulations and favor adaptation, though these are more conservative perspectives on energy and climate. In general, results on adapting to a warmer climate are as expected, with gender offering the greatest practical significance, followed by square footage of home and vehicle holdings. Similarly, a respondent's age, local household density and home size variables exhibit the greatest practical significance in opinions on imposing regulations.

Younger respondents and those from higher-income (per member) households are more likely to support regulations, perhaps because the latter can better afford higher energy prices, home investments, and the like. Interestingly, neither age nor income was not a statistically significant predictor in the adaptation model, but higher neighborhood income is associated with greater support for adaptation.

Notably, smaller home size, home ownership, more central locations and higher densities are all markers for respondents that are more likely to favor regulations and favor adaptation (or at least expect that adaptation is needed). Persons with more energy efficient lifestyles (such as more central dwellers, in smaller homes) may be more supportive of regulation, since such regulation may require less change in their lifestyles (and they may have more options in terms of mode choice and trip destinations, for example).

Table 8: Model Results for Opinions on What Should Be Done about Climate Change

\begin{tabular}{|l|c|c|c|c|c|c|}
\hline & \multicolumn{3}{|c|}{ Adapt to a Warmer Climate } & \multicolumn{3}{c|}{ Regulations Should be Imposed } \\
\hline Explanatory Variables & Coefficient & $\begin{array}{c}\text { T- } \\
\text { statistic }\end{array}$ & $\begin{array}{c}\text { Mean elasticity for } \\
\text { agreement }\end{array}$ & Coefficient & $\begin{array}{c}\text { T- } \\
\text { statistic }\end{array}$ & $\begin{array}{c}\text { Mean elasticity } \\
\text { for agreement }\end{array}$ \\
\hline Constant & -1.842 & -5.30 & - & 0.9243 & 3.43 & - \\
\hline Age of respondent & - & - & - & -0.1468 & -3.63 & -0.9650 \\
\hline Female indicator & -0.5626 & -5.26 & -0.9414 & 0.2725 & 2.73 & 1.3418 \\
\hline Worker status & 0.2709 & 1.92 & 0.1378 & -0.3179 & -2.11 & -0.7459 \\
\hline $\begin{array}{l}\text { Number of vehicles owned } \\
\text { by household }\end{array}$ & 0.3563 & 4.33 & 0.8934 & -0.1085 & -1.42 & -0.0752 \\
\hline $\begin{array}{l}\text { Income per person (total } \\
\text { income/household size) }\end{array}$ & - & - & - & $4.20 \mathrm{E}-06$ & 1.79 & 0.0946 \\
\hline Square footage of home & $-3.47 \mathrm{E}-04$ & -4.34 & -1.036 & $-2.03 \mathrm{E}-04$ & -3.18 & 0.4580 \\
\hline Own home & 0.4909 & 3.30 & 0.3876 & 0.2267 & 1.70 & 0.0959 \\
\hline
\end{tabular}

\footnotetext{
${ }^{3}$ Respondents reported their opinions on "What the U.S. should do about climate change", with the dependent variable being binary.
} 


\begin{tabular}{|l|c|c|c|c|c|c|}
\hline Distance to CBD & -0.0293 & -2.48 & -0.3244 & -0.0236 & -2.23 & -1.457 \\
\hline $\begin{array}{l}\text { Household density } \\
\text { (households per acre in } \\
\text { TAZ) }\end{array}$ & 0.1097 & 3.25 & 0.3379 & 0.1095 & 3.20 & 0.8541 \\
\hline Median income of zone & $8.48 \mathrm{E}-06$ & 5.37 & 0.6724 & - & - & - \\
\hline $\begin{array}{l}\text { Log Likelihood at } \\
\text { Convergence }\end{array}$ & \multicolumn{3}{|c|}{-383.9} & & -449.9 \\
\hline Pseudo R & \multicolumn{3}{|c|}{0.1267} & & 0.0895 \\
\hline
\end{tabular}

Note: A binary probit model was used for each response since the dependent variable is binary (yes/no), and $\mathrm{n}=717$.

Elasticities were evaluated at each record's attributes and then averaged, to provide a mean elasticity across

households/respondents.

\section{Capping Energy Use vs. Taxing All Energy Use}

While some form of energy regulation seems to be reasonably popular (59.8\%?) in these Austin results ${ }^{4}$, one wonders which form will garner maximum public support. Two prevailing options for abatement of carbon emissions are a cap-and-trade system and a carbon emissions tax. Cap refers to a maximum limit on the amount of CO2 emissions that are emitted from energy use. A tax implies that energy users by default pay a tax for every ton of emissions produced. Existing studies have examined how associated costs would be borne by consumers (see, e.g., Lasky, 2003; Dinan and Rogers, 2002; and Kerkhof et al. 2008). Results from these studies suggest that the lowest one fifth of the income distribution would have to bear about $3.3 \%$ of their average income and the top quintile would pay about $1.7 \%$ of its average income.

In the first of these two options, the "cap" refers to an upper limit on the amount of carbon dioxide emissions that may be emitted from the use of electricity, oil, natural gas, food and other fuels. "Trade" refers to the system in which households or firms can buy or sell the rights to emit carbon, called credits. By contrast, a carbon tax is less complex, requiring that carbon emitters pay a tax for every ton of GHG emissions they produce. The government sets a price per ton on carbon, which translates to fuel taxes. This would induce households and firms to reduce consumption and move towards more carbon efficient means (for instance shifting to more fuel efficient vehicles). While there is more certainty in pricing under this second option, the nation may not hit (or may overshoot) its target (e.g., an 80\% reduction in GHG emissions by 2050).

As presented in Table 9, only 2.8\% of Austinites appear willing to state that they completely support both policies. A fair number (21.9\%) agree that a cap should be placed on energy use, but not all energy use should be taxed. Interestingly, among the $36.70 \%$ somewhat supporting the cap policy (36.70\%), $11.40 \%$ only somewhat support and $11.20 \%$ somewhat oppose a taxation policy. There is substantial variation in support across options here, and correlation between the paired set of ordered responses is just +0.17 . Finding regulations that most parties can accept will be contentious.

\footnotetext{
${ }^{4}$ Potoglou and Kanaroglou (2007) have remarked that in stated choice experiments, respondents report being more protective of the environment than they really are. The lower lack of support that emerges once specific policies are introduced to respondents here (as shown in Table 9, vs. Table 3's more generic responses) suggests that specificity may also make a difference, with more specific questions being more realistic.
} 
Table 9: Comparison of Responses for Opinions on Capping Maximum Energy Use and Taxing Energy Use (Weighted Shares)

\begin{tabular}{|c|c|c|c|c|c|c|c|}
\hline \multirow{2}{*}{\multicolumn{2}{|c|}{$\begin{array}{l}\text { Respondent Shares } \\
\text { (weighted) }\end{array}$}} & \multicolumn{6}{|c|}{ Tax on all energy use } \\
\hline & & \multirow{2}{*}{$\begin{array}{c}\text { Strongly } \\
\text { Support } \\
23 \\
2.80 \% \\
\end{array}$} & \multirow{2}{*}{$\begin{array}{c}\begin{array}{c}\text { Somewhat } \\
\text { Support }\end{array} \\
36 \\
4.30 \% \\
\end{array}$} & \multirow{2}{*}{$\begin{array}{c}\text { Neutral } \\
18 \\
2.20 \%\end{array}$} & \multirow{2}{*}{$\begin{array}{c}\begin{array}{c}\text { Somewhat } \\
\text { Oppose }\end{array} \\
25 \\
3.00 \% \\
\end{array}$} & \multirow{2}{*}{$\begin{array}{c}\begin{array}{c}\text { Strongly } \\
\text { Oppose }\end{array} \\
24 \\
2.90 \% \\
\end{array}$} & \multirow{2}{*}{$\begin{array}{c}\text { Total } \\
126 \\
15.20 \%\end{array}$} \\
\hline \multirow{6}{*}{ 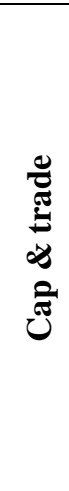 } & $\begin{array}{l}\text { Strongly } \\
\text { Support }\end{array}$ & & & & & & \\
\hline & $\begin{array}{c}\text { Somewhat } \\
\text { Support }\end{array}$ & $\begin{array}{c}24 \\
2.90 \% \\
\end{array}$ & $\begin{array}{c}95 \\
11.40 \% \\
\end{array}$ & $\begin{array}{c}53 \\
6.40 \% \\
\end{array}$ & $\begin{array}{c}93 \\
11.20 \% \\
\end{array}$ & $\begin{array}{c}40 \\
4.80 \% \\
\end{array}$ & $\begin{array}{c}305 \\
36.70 \% \\
\end{array}$ \\
\hline & Neutral & $\begin{array}{c}7 \\
0.80 \%\end{array}$ & $\begin{array}{c}29 \\
3.50 \%\end{array}$ & $\begin{array}{c}67 \\
8.10 \%\end{array}$ & $\begin{array}{c}25 \\
3.00 \%\end{array}$ & $\begin{array}{c}9 \\
1.10 \% \\
\end{array}$ & $\begin{array}{c}137 \\
16.50 \%\end{array}$ \\
\hline & $\begin{array}{c}\text { Somewhat } \\
\text { Oppose }\end{array}$ & $\begin{array}{c}3 \\
0.40 \% \\
\end{array}$ & $\begin{array}{c}49 \\
5.90 \% \\
\end{array}$ & $\begin{array}{c}17 \\
2.00 \% \\
\end{array}$ & $\begin{array}{c}56 \\
6.70 \% \\
\end{array}$ & $\begin{array}{c}13 \\
1.60 \% \\
\end{array}$ & $\begin{array}{c}138 \\
16.60 \% \\
\end{array}$ \\
\hline & $\begin{array}{c}\text { Strongly } \\
\text { Oppose }\end{array}$ & $\begin{array}{c}9 \\
1.10 \% \\
\end{array}$ & $\begin{array}{c}22 \\
2.60 \% \\
\end{array}$ & $\begin{array}{c}19 \\
2.30 \% \\
\end{array}$ & $\begin{array}{c}21 \\
2.50 \% \\
\end{array}$ & $\begin{array}{c}54 \\
6.50 \% \\
\end{array}$ & $\begin{array}{c}125 \\
15.00 \% \\
\end{array}$ \\
\hline & Total & $\begin{array}{c}66 \\
7.90 \% \\
\end{array}$ & $\begin{array}{c}231 \\
27.80 \% \\
\end{array}$ & $\begin{array}{c}174 \\
20.90 \% \\
\end{array}$ & $\begin{array}{c}220 \\
26.50 \% \\
\end{array}$ & $\begin{array}{c}140 \\
16.80 \% \\
\end{array}$ & $\begin{array}{c}831 \\
100.00 \% \\
\end{array}$ \\
\hline
\end{tabular}

Using Sajaia’s (2005) STATA code, a bivariate ordered probit model was used to analyze whether a cap should be placed on maximum energy use or whether all energy used should be taxed. Table 10's parameter results suggest that younger respondents with the highest significance level and those residing in newer housing units are more supportive of either style of regulation, everything else constant. They may be more concerned about climate change, since it will have a greater impact on their lives than on those who may not be around for many of the longer-term and more devastating impacts. And this finding is consistent with those of Bannon et al. (2007). Those from higher-income households, women and non-workers are more likely to support energy taxes, along with those in larger households.

Though the two dependent variables represent opinions on two distinct policies, the correlation coefficient is positive (0.1792) and significant at the 95\% confidence level, suggesting that, ceteris paribus, latent effects lead respondents to either favor (or not support) both strategies in their survey responses. While this is not surprising, it is useful to have a sense of how strong these correlations are, as other policy options (and variations on these two options) emerge.

Table 10: Model Results for Opinions on Capping Maximum Energy Use and Taxing All Energy Use

\begin{tabular}{|l|c|c|c|c|}
\hline & \multicolumn{2}{|c|}{$\begin{array}{c}\text { Cap on Maximum Energy } \\
\text { Use }\end{array}$} & \multicolumn{2}{c|}{ Taxing all Energy Use } \\
\hline Explanatory Variables & Coefficient & T-statistic & Coefficient & T-statistic \\
\hline Number of vehicles owned by household & -0.1174 & -2.37 & 0.0772 & 1.39 \\
\hline Age of respondent & - & - & 0.2137 & 7.14 \\
\hline Female & 0.1739 & 2.36 & -0.1587 & -2.11 \\
\hline Worker status & - & - & 0.2591 & 2.38 \\
\hline $\begin{array}{l}\text { Income per person (total income/household } \\
\text { size) }\end{array}$ & $-3.47 \mathrm{E}-06$ & -2.13 & - & - \\
\hline Household size & 0.0338 & 1.74 & -0.0319 & -1.54 \\
\hline Own home & - & - & -0.2032 & -2.02 \\
\hline Age of home & $-3.52 \mathrm{E}-03$ & -1.84 & $-6.13 \mathrm{E}-03$ & -2.99 \\
\hline Square footage of home & - & - & $2.39 \mathrm{E}-04$ & 4.64 \\
\hline Threshold 1 & -1.786 & -12.49 & -0.1828 & 0.97 \\
\hline Threshold 2 & -0.5681 & -4.30 & 0.9261 & 4.89 \\
\hline
\end{tabular}




\begin{tabular}{|l|c|c|c|c|}
\hline Threshold 3 & 0.0223 & 0.17 & 1.352 & 7.07 \\
\hline Threshold 4 & 0.8272 & 6.23 & 2.122 & 10.78 \\
\hline Log Likelihood at Convergence & \multicolumn{5}{|c|}{-2430} \\
\hline Log Likelihood at Constants & \multicolumn{4}{|c|}{-2467} \\
\hline Covariance across equations' residuals & 0.1792 & 4.63 & - \\
\hline Adjusted LRI & \multicolumn{4}{|c|}{0.02067} \\
\hline
\end{tabular}

Note: A bivariate ordered probit model was used, and $n=814$.

\section{CONCLUSIONS}

Household energy use is a critical, yet complex, topic. This survey investigated household energy use patterns and energy policy opinions in the Austin metropolitan area. Very little research has been done on the connections between these patterns and opinions, despite the implications for future local, state, and national energy policies. Using a combination of revealed and stated preference questions, respondents provided insight into their daily energy use and their feelings about climate change and energy regulations. Through a variety of regression models, a great deal of information was obtained from the sample.

While nearly all Austinites' (95\% of the population-corrected sample) appear to agree that climate change is a concern, about $40 \%$ state an unwillingness to change their behavior. Energy caps and taxes are generally less supported by those who appear more directly affected by such policies (e.g., families with larger homes), and somewhat greater support appears to exist for caps than for taxation. Despite the potential impacts of such policies, 32\% and 43\% of Austin's (population-corrected) respondents are indifferent to these policies (direct taxation and consumption caps, respectively). Support for energy caps and energy taxes is positively correlated, confirming the notion that individuals who are more environmentally-conscious also feel positively about a variety of energy-reduction measures.

Women, younger persons and high income households are more supportive of taxing energy use and the imposition of energy-saving regulations. Respondent age, household size, income and vehicle ownership generally are strong predictors of current energy consumption (and thus probably future energy consumption). Results also suggest that higher transit access and reduced travel distances are associated with (and thus may help households transition to) more fuel efficient vehicles. Both population and jobs density variables appear to play key roles in models of annual VMT, fuel consumption, and, thus, carbon emissions. 93\% out of the 95\% respondents who believe that global warming is a problem, have an opinion that U.S. should do something about it. This result alone suggests that there is a rising concern among individuals to protect the environment.

There are significant opportunities for further research in this field. Larger sample sizes and surveys of energy policy across metropolitan areas, in the U.S. and abroad, can provide policy-makers and planners with a vital source of information for preferred policy directions. Moreover, further analysis of the energy usage behavior of households could provide insights into practical methods to reduce the energy required for daily activities. The results of this survey and future research are particularly important in light of current global warming and climate change policies being considered at all levels of government. 


\section{REFERENCES}

An, F. and A. Sauer. 2004. Comparison of Passenger Vehicle Fuel Economy and Greenhouse Gas Emission Standards Around the World. Pew Center on Global Climate Change. Accessed from http://www.pewclimate.org/docUploads/Fuel\%20Economy\%20and\%20GHG\%20Standards_010 605_110719.pdf on May 27, 2009.

Bannon, B., M. DeBell, and J. Krosnick 2007. Americans’ Evaluation of Policies to Reduce Greenhouse Gas Emissions. http://woods.stanford.edu/docs/surveys/GW_New_Scientist_Poll_Technical_Report.pdf

British Broadcasting Corporation BBC (2002) The U.S. and Climate Change. http://news.bbc.co.uk/2/hi/americas/1820523.stm. Accessed February 14, 2009.

Bhat, C.R., S. Sen, and N. Eluru. 2008. The Impact of Demographics, Built Environment Attributes, Vehicle Characteristics, and Gasoline Prices on Household Vehicle Holdings and Use. Transportation Research Part B, 43(1), 1-18.

Bomberg, M., M. Thompson, C. Whitehead, and K. Kockelman. 2008. GHG Emissions Control Options: Opportunities for Conversation. Report Commissioned by the National Academy of Sciences. http://www.ce.utexas.edu/prof/kockelman/public_html/NAS_CarbonReductions.pdf. Accessed on $29^{\text {th }}$ April 2009.

Clayton, M. 2007. How Green is Nuclear Power? Christian Science Monitor, March 7. Accessed at http://www.csmonitor.com/2007/0307/p01s04-sten.html on May 27, 2009.

Curry, T., S. Ansolabehere, and H. Herzog. 2007. A Survey of Public Attitudes towards Climate Change and Climate Change Mitigation Technologies in the United States: Analyses of 2006 Results. http://sequestration.mit.edu/pdf/LFEE_2007_01_WP.pdf.

Dinan, T, and Rogers, D. L. 2002. Distributional Effects of Carbon Allowance Trading: How Government Decisions Determine Winners and Losers. National Tax Journal, 55(2): 199-221.

Energy Information Agency (EIA). 2007. Emissions of Greenhouse Gases in the United States for 2006. Report No. DOE/EIA-0573 http://www.eia.doe.gov/oiaf/1605/ggrpt/pdf/enduse_tbl.pdf. Accessed December 27, 2009.

Fang, H. 2008. A Discrete-Continuous Model of Households' Vehicle Choice and Usage, with an Application to the Effects of Residential Density. Transportation Research Part B, 42(9), 736758.

Feng, Y., D. Fullerton, and L. Gan. 2005. Vehicle Choices, Miles Driven and Pollution Policies. Working paper 11553, National Bureau of Economic Research.

Gallagher, K., and E. Muehlegger. 2007. Giving Green to Get Green? The Effect of Incentives and Ideology on Hybrid Vehicle Adoption. John F. Kennedy School of Government Faculty Research Working Paper Series.

Gärling, T., and K.W. Axhausen. 2003. Introduction: Habitual Travel Choice. Transportation, 30(1): $1-11$.

Goldberg, P.K. 1998. The Effects of the Corporate Average Fuel Efficiency Standards in the U.S. The Journal of Industrial Economics, 46(1): 1-33.

Greene, D.L., J.R. Kahn, and R.C. Gibson. 1999. Fuel Economy Rebound Effect of U.S. Household Vehicles. Energy Journal, 20(3): 1-31.

Greene, W. 2000. Econometric Analysis. 4th edition. Prentice-Hall, NJ.

Heffner, R., K. Kurani, and T. Turrentine. 2007. Symbolism in Early Markets for Hybrid Electric Vehicles. Technical Paper, Institute of Transportation Studies, University of California, Davis.

Kerkhof A. C., H.C. Moll, E. Drissen and H.C. Wilting. 2008. 'Taxation of multiple greenhouse gases and the effects on income distribution: a case study of the Netherlands. Ecological Economics, 318-326. 
King, S., M. Dyball, T. Webster, A. Sharpe, A. Worley, and J. DeWitt. 2009. Exploring Public Attitudes to Climate Change and Travel Choices: Deliberative Research. United Kingdom's Department for Transport.

http://www.dft.gov.uk/pgr/scienceresearch/social/climatechange/attitudestoclimatechange.pdf.

Kitamura, R., and T. van der Hoon. 1987. Regularity and Irreversibility of Weekly Travel Behavior. Transportation, 14(3): 227-251.

Kurani, K., and T. Turrentine. 2004. Automobile Buyer Decisions about Fuel Economy and Fuel Efficiency. Final Report to United States Department of Energy and Energy Foundation.

Lasky, M. 2003. The Economic Costs of Reducing Emissions of Greenhouse Gases: A Survey of Economic Models, CBO Technical Paper 2004-4.

Mohammadian, A., and E. J. Miller, 2003. An Empirical Investigation of Household Vehicle Type Choice Decisions, Transportation Research Record: Journal of Transportation Board, 99-106.

NAHB. 2008 Median and Average Square Feet of Floor Area in New One-Family Houses Sold by Location. National Association of Home Builders. http://www.nahb.org/page.aspx/category/sectionID=130. Accessed on $28^{\text {th }}$ October 2008.

NHTS. 2001. National Household Travel Survey. Oak Ridge National Laboratory. Oak Ridge, TN. Available at http://nhts.ornl.gov/.

Potoglou, D., and P. Kanaroglou. 2007. Household Demand and Willingness to Pay for Clean Vehicles, Transportation Research Part D, 12 (4), 264-274.

Prillwitz, J., S. Harms, and M. Lanzendorf. 2008. Impact of Life Course Events on Car Ownership. Poster for the 85th Annual Meeting of the Transportation Research Board, Washington, D.C., January 22-26, 2006.

Puller, S.L., and L.A. Greening. 1999. Household Adjustment to Gasoline Price Change: An Analysis Using 9 Years of US Survey Data. Energy Economics, 21(1): 37-52.

RECS. 2001. Residential Energy Consumption Survey Data. U.S. Energy Information Administration. Washington, D.C. Available at http://www.eia.doe.gov/emeu/recs/.

Sajaia, Z. 2005. BIOPROBIT: State Module for Bivariate Ordered Probit Regression. Statistical Software Components, Boston College Department of Economics. Available at http://econpapers.repec.org/software/bocbocode/s456920.htm. Accessed on $2^{\text {nd }}$ April 2009.

Searchinger, T., et al. 2008. Use of U.S. Croplands for Biofuels Increases Greenhouse Gases Through Emissions from Land-Use Change. Science, 319(5867): 1238-1240.

Small, K.A., and K. van Dender. 2007. Fuel Efficiency and Motor Vehicle Travel: The Declining Rebound Effect. Energy Journal, 28(1): 25-51.

Smith, C., M. Fowler, E. Greene, and C. Nielson. 2009. Carbon Emissions and Climate Change: A Study of Attitudes and their Relationship with Travel Behavior. Presentation to the Transportation Research Board’s National Transportation Planning Applications Conference, May 2009.

Thorpe, S.G. 1997. Fuel Economy Standards, New Vehicle Sales, and Average Fuel Efficiency. Journal of Regulatory Economics, 11(3): 311-326.

Zhao, Y. and K. M. Kockelman. 2001. Household Vehicle Ownership by Vehicle Type: Application of a Multivariate Negative Binomial Model. Proceedings of the Transportation Research Boards 81st Annual Meeting, Washington, D.C. 